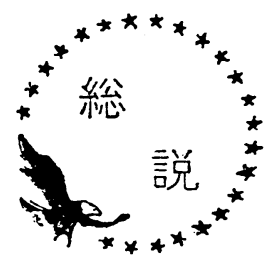

1. まえがき

わが国経済の驚異的な発展にともないエネルギ一需 要は著しく増加している。エネルギー種別では, 原油 輸入量の増大を中心に輸入エネルギー比率が昭和50年 度には $80 \%$ を越える予想であるから，海外資源の確保 と輸送の安全は国益上重要な問題である。

わが国における一次エネルギーの供給源の大部分は 石油に頼っているが，亜硫酸ガスによる都市公害, 産 業公害などの防止対策上から，硫黄分がないエネルギ 一源である天然ガスの利用が大きく浮び上がってき た。しかも，これまでパイプラインでしか輸送できな かった LNGを, $-162^{\circ} \mathrm{C}$ という超低温で液化して海 上輸送できる技術が開発され，世界各地から LNG を 輸送する体制が整ってきたので, これに対応する輸 送, 貯蔵, 消費ならびに寒冷利用に積極的な技術開発 が必要とされている。すでに45年11月に東京瓦斯, 東 京電力の LNG 輸入が実現し, 根岸にわが国最初の LNG 基地建設に続き，大阪瓦斯泉北工場の $\mathrm{LNG}$ 基 地にはアルミニウム合金製貯槽の実現をみるに至って いるが，LNG キャリヤにおいては技術提携による国 産第 1 船の就航は 52 年頃と予想される。

今後数年間に著しいメタニゼーションが伸展 し, LNG が内陸でサテライトステーションといわれる衛 星貯蔵基地によるガス供給の段階に至れば, タンクロ ーリーあるいはタンク車による輸送が問題となるだろ う。

通産省では44年度に「液化天然ガス研究委員会」を 設置し，その調查報告が45年 3 月にまとめられ， $\mathrm{LNG}$ の車両輸送についても言及している。それは欧米にお ける車両輸送の実態と車両の仕様に関係する技術情報 として意義がある（表 1 )。わが国では高圧ガス取締 法, 道路運送車両法, 国鉄車両管理規定などの規制を 受けるほか保安面から運行および取扱い上の行政指導 が新しい問題として起こってくるので, 安全性と経済 性の妥協を求めつつ技術上の問題を解決しなければな らない。とくに欧米とわが国の国土および習慣の相違 から, 海外の実例をそのまま内陸輸送車両に適用する
ことに抵抗があるので, 行政官庁, 使用者, メーカー の 3 者の協力と合意が必要である。

高圧ガス保安協会は 45 年 3 月, 通産省加ら「LNG タンクローリー保安技術基準」の作成を委託され，46 年 3 月にまとめて答申している。この基準は LNG 容 器の設計, 工作, 検查に関し通産省令「容器保安規 則」に準拠し, 容器および道路運送車両として LNG を安全に輸送し，かつ安全に取り扱うことを前提とし た安全装置ならびに使用者側に対する取扱いも含めた 技術基準である。東京瓦斯ではすでに横浜一日立間の LNG 輸送に LNG 専用のタンクローリーを運行させ ているが, 交通事情の悪化, 危険物運送車両の通行制 限が厳しくなりつつあるため鉄道輸送の検討も始めら れている。

超低温液化ガスでも酸素, 窒素, アルゴンなどは古 くからタンクローリ一輸送が行なわれているが, 鉄道 タンク車としては経験がないため LNG タンク車の実 現には LNG ローリ一以上に問題が多く, 各界の協力 による開発体制の確立が望まれる。

ここでは LNG ローリーの安全性について述べる。

\section{2. 充てん定数}

液化天然ガスは産地および精製方法により主成分の メタンのほかエタン，プロパン，窒素など随伴ガスに よる密度の変化がみられる。

LNG を充てんする容器は, 常用の温度のうち最高 のものにおける LNG の比重をもとに $10 \%$ の気相空間 を残すよう規定されているが, 常用の温度のうち最高 のもののとり方に疑問があり, 場合によっては同一容 器でも充てん質量が変わるといら不便を生じる。

車両は最大積載量をべースに設計上の限度や法規上 の制限があり, 最大積載量の決定は容器の内容積 と LNG 積載重量により決まるので, 比重の決め方は設 計上重要な要素でもある。

常温液化ガス容器では, 容器の最高充てん圧力 (55 ${ }^{\circ} \mathrm{C} に お け る$ 蒸気圧）において $5 \%$ の空間率をむつよう 液化ガスの比重の逆数を充てん定数として定めてある ので, 安全弁作動時には $2 \sim 3 \%$ 空間率がある。 


\section{表 1 LNG 専用輸送車両の例}

\begin{tabular}{|c|c|c|c|c|c|c|c|}
\hline 籍 & 作 & 積 & 設計圧力 & 容 & 主な方 法 & 断熱方式 & \\
\hline アメリカ & $\begin{array}{l}\text { LOX EQUIPMENT } \\
\text { COMPANY }\end{array}$ & タンク車 & - & $\begin{array}{l}34,200 \\
\text { ガロン }\end{array}$ & & 真空断熱 & $\begin{aligned} \text { 内タンク : } \\
\text { ステンレス }\end{aligned}$ \\
\hline アメリカ & LOX & $\begin{array}{l}\text { セミトレ } \\
\text { ーラー }\end{array}$ & 30 psig & $\begin{array}{l}\text { 38,200 } \\
\text { ポンド }\end{array}$ & 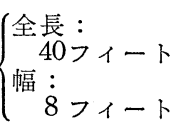 & 真空断熱 & $\left\{\begin{array}{c}\text { 内タンク : } \\
\text { ステンレス } \\
\text { 総 重 量: } \\
57,400 \text { ポンド }\end{array}\right.$ \\
\hline アメリカ & $\begin{array}{l}\text { Cosmadyne } \\
\text { CORPORATION }\end{array}$ & $\begin{array}{l}\text { セミトレ } \\
\text { ーラー }\end{array}$ & 40 psig & $\begin{array}{l}11,550 \\
\text { ガロン }\end{array}$ & 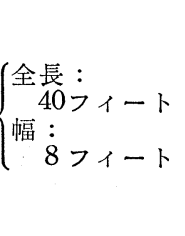 & 真空断熱 & $\begin{array}{l}\text { 空車重量: } \\
21,500 \text { ポンド } \\
\text { 総 重 量: } \\
61,080 \text { ポンド } \\
\text { 内タンク : } \\
\text { ステンレス } \\
\text { 蒸 発率: } \\
0.5 \% / \text { 日 }\end{array}$ \\
\hline アメリカ & $\begin{array}{l}\text { Process Engineering } \\
\text { Inc }\end{array}$ & $\begin{array}{l}\text { セミトレ } \\
\text { ーラー }\end{array}$ & 56 psig & $\begin{array}{l}11,600 \\
\text { ガロン }\end{array}$ & & 真空断熱 & 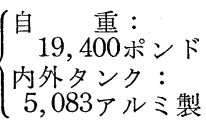 \\
\hline 独 & $\begin{array}{l}\text { Messer Greisheim } \\
\text { CmbH }\end{array}$ & $\begin{array}{l}\text { セミトレ } \\
\text { ーラー }\end{array}$ & $56.9 \mathrm{psig}$ & $8,800 \mathrm{~kg}$ & $\left\{\begin{array}{l}\text { 全 長 : } \\
425.2 \text { インチ } \\
\text { 幅: } \\
137.8 \text { インチ }\end{array}\right.$ & 真空断熱 & $\begin{aligned} \text { 内タンク: } \\
\text { ステンレス }\end{aligned}$ \\
\hline イギリス & $\begin{array}{l}\text { Linke Hotman-Busch } \\
\text { Waggn Fahrseug } \\
\text { Machinen CmbH }\end{array}$ & タンク車 & $3 \mathrm{~kg} / \mathrm{cm}^{2}$ & $54,000 l$ & $\left\{\begin{array}{c}\text { 全 長 : } \\
16,700 \mathrm{~mm} \\
\text { 最大高さ: } \\
4,100 \mathrm{~mm}\end{array}\right.$ & 真空断熱 & 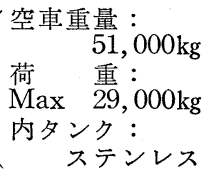 \\
\hline イギリス & $\mathrm{BOC}$ & $\begin{array}{l}\text { セミトレ } \\
\text { ーラー }\end{array}$ & 100 psig & $14 \mathrm{t}$ & & $\begin{array}{l}\text { ポリウレ } \\
\text { タン断熱 }\end{array}$ & \\
\hline フランス & $\begin{array}{l}\text { Ateliers de } \\
\text { Chaudromnerie } \\
\text { Alpes-Rnone }\end{array}$ & $\begin{array}{l}\text { セミトレ } \\
\text { ーラー }\end{array}$ & $7 \mathrm{~kg} / \mathrm{cm}^{2}$ & $42,000 l$ & $\begin{array}{l}\text { 全 長 : } \\
11,630 \mathrm{~mm} \\
\text { 全 高 : } \\
3,860 \mathrm{~m} \mathrm{~m} \\
\text { 内タンク } \\
\text { 内径 : } \\
\text { 異径胴 } 2,100 \\
2,300\end{array}$ & $\begin{array}{l}\text { ポリウレ } \\
\text { タン発泡 } \\
\text { 断熱 }\end{array}$ & 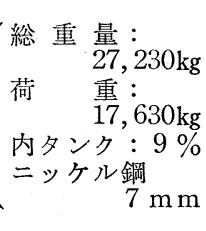 \\
\hline
\end{tabular}

（注）通産省鉱山石炭局 液化天然ガス研究委員会報告（45年 3 月）による。

LNG タンクローリーでは, 省令でいら充てん定数 をどのように扱うかを検討した結果，アメリカ圧縮ガ ス協会制定の CGA-341 では安全弁の設定圧力によ り許容最高充てん限度を決めており, その定め方は図 1 に示寸ように, 充てん後液が膨張して, 液で満杯と なる圧力（温度）となっている。またわが国での液化 酸素タンクローリーの場合は, 酸素の沸点における液 比重を用いて充てん定数を決めており, 液膨張による 満液直前 (空間率 $2.4 \%$ ) で安全弁が作動するように なっている。いずれの場合も, 輸送中における外熱の 侵入により液温が上がり容器が液膨張で破裂しないよ う若干の空間容積が残っている状態で安全弁を作動さ せることにしている。省令の規定を厳密に適用する と, 最高充てん圧力に対応する液比重において空間率 10\%もつことになるので, 車両として積車効率の悪い ものとなる。通常 $\mathrm{LNG}$ 貯槽は $0.5 \mathrm{~kg} / \mathrm{cm}^{2}$ 以下で設
計され沸点に近いところで貯蔵されているので容器へ の充てん後の温度は沸点に近いか過冷却の状態と考光 られるので，最高充てん圧力に抢ける LNG の比重を とらず, 液化酸素のローリーと同様沸点における比重 をとり充てん後の空間率が10\%, 安全弁作動直前の空 間率が 2 \%になるよら決められた。なお委託基準では LNG の充てん定数として，LNG 第 1 種 (メタンの 含有量 $99 \%$ 以上のもの) は $2.63, \mathrm{LNG}$ 第 2 種 (メタ ンの含有量 $99 \%$ 未満のもの) は 2.36 と定められた。

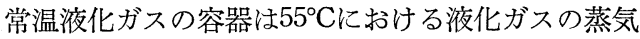
圧を最高充てん圧力とし，かつ $40^{\circ} \mathrm{C}$ 以下に保つよう規 制されているので, 満液になる状態は過充てんをやら ないかぎり火災などの異常時に限られるが，超低温容 器では断熱性能の劣化傾向, 車両の振動による圧力計 の狂い, 液面計の器差などにより輸送中における監視 だけでは満液状態になるおそれに対する安全対策には 


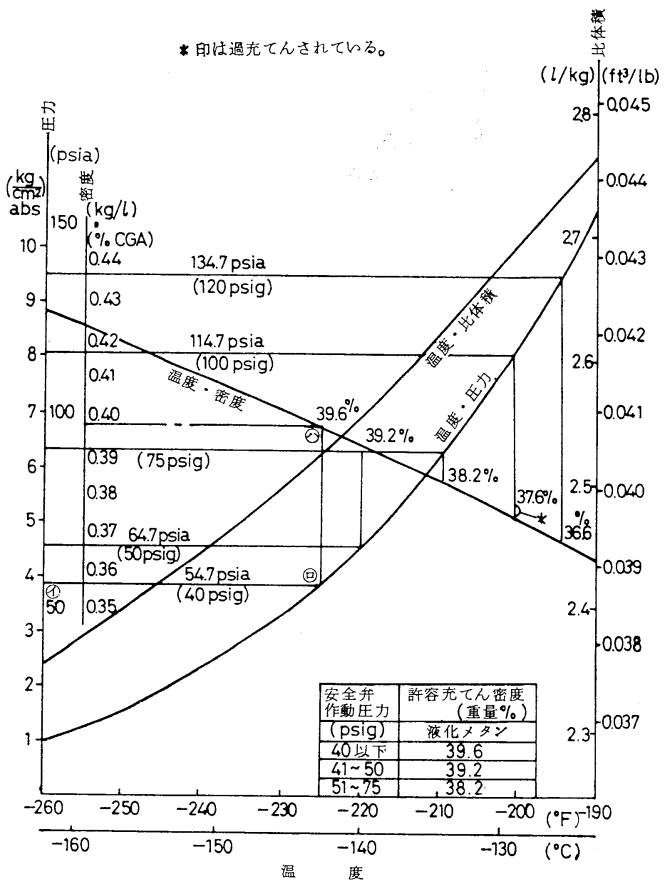

図 1 液化メタン (Matheson Co. ハンドブック p. 321 表 1 より物性值, CGA-341 p. 13 よ り圧力・充てん密度を求めた）

ならないので, 充てん時に比重の確認と検出管による 最高充てん液面の確認を行ない, 容器に対する過充て ん防止と車両最大積載量の超過防止に一段の注意が必 要である。

\section{3. 最高充てん圧力}

最高充てん圧力とは, 圧縮ガスの場合温度 $35^{\circ} \mathrm{C}$ にお いてその容器に充てんすることのできるガスの圧力の うち最高のものと定義されており, 法規上, 容器に対 する最高充てん圧力の刻印, 容器証明書に対する記載 が行なわれているが，超低温容器の場合は常用の圧力 のうち最高のものの数值と定義され，容器に対する刻 印も容器証明書に対する記載も行なわれない。最高充

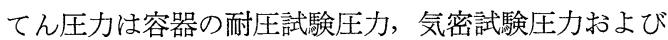
安全弁作動圧力を決める根拠となる圧力である。超低 温容器においてこれらの関係を明らかにしておかない と充てん, 移送, 容器再検などにおいて混乱を起こす おそれがある。超低温容器の最高充てん圧力の決め方 は, 通常タンクローリー運行中の熱侵入による液温上 昇に伴う圧力上昇分に不慮の事故の場合を考光，3 4 日の余裕を加味して設定されるのが普通である。し かし LNG ローリーでは液払出しのとき加圧蒸発器を
用いて最高充てん圧力以上に加圧して圧送する場合が あり，この場合には加工される最高圧力をもとに耐圧 試験圧力, 安全弁作動圧力を決めなければならない。 また真空断熱容器では真空による外圧 $1.03 \mathrm{~kg} / \mathrm{cm}^{2}$ を 耐圧試験圧力にプラスシンの圧力をもとに安全弁作動 圧力が決まる。

現行省令では充てん定数および最高充てん圧力の定 義を超低温容器に対し常用の温度, 圧力のらち最高の ものとしているが, 前述のごとく最高の数值を定める ことが困難である。この点について委託基準によると 容器の部分と高圧ガス設備の部分に分けて解説されて いる。すなわち次のとおりである。

(1) 最高充てん圧力は容器に $4 \mathrm{~kg} / \mathrm{cm}^{2}$ 以下で作動 する安全弁を設けるので $3 \mathrm{~kg} / \mathrm{cm}^{2}$ 以下で充てん するものとするが，充てん定数を決める関係から 充てん後の容器内の LNG の状態は沸点に近いも のとする。

(2) 設計圧力は加圧蒸発器で加圧する圧力の最高を とり, 真空断熱容器の場合は $1.03 \mathrm{~kg} / \mathrm{cm}^{2}$ を加 えた数值とする。

(3) 耐圧試験圧力は常用圧力により決めた肉厚に対 寸る耐圧性能が目的であるから, 高圧ガス設備が 受ける圧力のうち最高のもの（最高使用圧力）の $5 / 3$ 倍以上の圧力とする。

(4) 運行中は(1)項の安全弁を使用し火災時などの液 膨張により満杯となる直前に作動させ, 別に最高 使用圧力に対応する安全弁を設け加圧払い出しを 可能にする。

\section{4. 容器の設計}

LNG タンクローリーの容器は容器保安規則で定義 されている超低温容器であって, 容器の材料, 母材お よび溶接に対する検查試験方法, 断熱性能などが決め られているので基本的には規則に適合するものでなけ ればならない。

$\mathrm{LNG}$ の沸点は $-162^{\circ} \mathrm{C}$ で, これ以下の低温の液化 酸素, 液化窒素のローリーがすでに多数稼動している ので, 容器本体に対する問題として LNG 特有の事柄 はない。LNG および液化エチレンは可燃性ガスであ るからガスを放出しながら運行する液化酸素, 液化窒 素の場合と違った保安上の措置をとらなければならな い。

内槽の設計圧力は, 運行中の熱侵入による圧力上昇 すなわち断熱性能, LNG の払出し方法および払出し 先の受入れタンクの圧力により決められる。粉末真空 断熱容器の場合は断熱性能が優れて抢り圧力上昇も比 
較的ゆるやかであるが，万一真空度が劣化しても最少 限度の運行が可能なよらに考慮しておかなければなら ない。

外槽は真空断熱の場合, 大気圧による外圧を受ける 容器としての強度が必要であるが, 車両として重量, 重心高は最大安定傾斜角度に及ぼす影響が大きな要素 となるから軽量化が必要となる。アメリカの CGA 規 格 MC-341 では鋼製の外槽の破壊に対する安全係数 を2 以上とし，ASME CODE SECTION VIII を準用 するよう規定し, 円筒部, 鏡板, 補強リングの肉厚計 算において ASME の算式が安全係数を 4 としている ので外圧を $7.5 \mathrm{psi}$ にとって計算することを認めてい る。

わが国では真空容器の設計基準が確立されておら ず, 各社で種々の計算式が用いられているのが現状で ある。LNG の委託基準でも細かな規定はなく最小板 厚として，鋼板の場合 $2.3 \mathrm{~mm}$, アルミニウム板の場 合 $3.2 \mathrm{~mm}$ と定められているにすぎない。

内槽の支持方法は Know-How に属するものが多 く詳細は明らかでないが，外槽からの伝熱を遮断する ため支持部分および締結部分に圧縮強度を有する熱絶 縁材料を用いる方法, 引張部材により㲘垂あるいは軸 方向を支持する方法, これらの組合せなどが考えられ る。いずれも内槽の膨張収縮に対し外槽と相対的に可 撓性をもつもので, かつ車両特有の振動, 衝撃, 横転 などに対し十分な強度が必要である。

図 2 は LNG 容器のあらましを示したもので, 内槽 から外槽へ貫通する多数の配管を装備しており, 配管 に対する可撓性, 内槽あるいは外槽内配管からの異状 漏洩に対する外槽破裂防止装置, 内槽予冷用シャワー 管などが一般に設けられている。

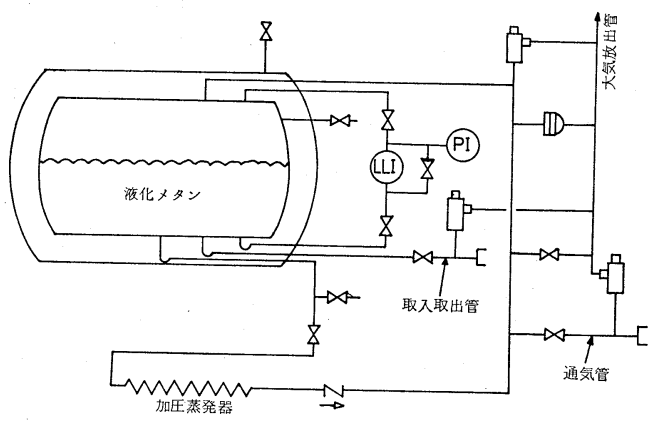

図 2 液化メタントレーラーのフローシート

\section{5. 断 熱性 能}

超低温容器の断熱性能は容器内の液化ガスの圧力上
昇速度の問題であり，ガスコスト中に占める輸送費を 低減させるため容器を軽量化し, 容積効率を高め, か つ保安上からも低圧であることが望ましいから，低圧 で長く保持できる容器が要求される。

超低温容器に応用できる断熱法には粉末常圧断圧, 高真空断熱, 粉末真空断熱および積層真空断熱などが ある。粉末常圧断熱法は内外槽の間に断熱材としてパ ーライトを封入したもので，比較的安価製作できる が断熱性能が劣るため最近ではほとんど用いられてい ない。積層真空断熱法は図 4 亿示すように最もすぐれ た断熱法で, 前述のパーライトの代りにガラスウール とアルミ䇴をサンドイッチに重社て挿入し，その空間 を高真空にしたものである。この方法はスーパーイン シュレーションともいわれるように非常に断熱性能が 良いのが特長であるが，施工技術，真空技術などに高 度のものが要求され, 製品のコストがきわめて高価に なるので, 現在は小型の容器にしか使用されない。現 在液化酸素, 液化窒素のローリーに採用されている粉 末真空断熱法は, LNG ローリーにも最適の方法であ る。これは断熱空間に粉末の断熱材 (パーライトな ぞ）を充てんし真空排気することにより熱輻射や残留 ガスによる熱伝導を減少させたものである。

現行省令では超低温容器の断熱性能の最低基準とし て, 侵入熱量 $0.002 \mathrm{kcal} / \mathrm{hr}$. deg. C.l があり，これは 非真空のパーライト断熱でも十分達成できるものであ る。図 3 亿示寸と抢り常圧断熱の場合は 100 時間前後

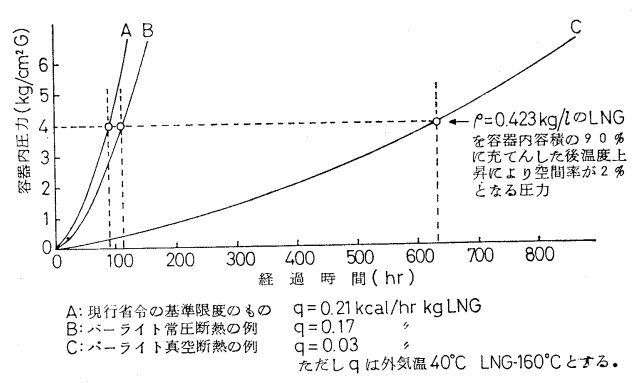

図 3 LNG タンクローリーの走行時間一圧カ上昇

であり, 中距離用輸送容器として十分考えられるが, 社会資本の立ち遅れているわが国の道路交通事情, 人 口, 都市の過密, 世論, 事故発生時の救援に要する時 間などを考虑して LNG ローリーに対する断熱性能は 省令よりも厳しく, その断熱性能試験に抢ける侵入熱 量を $0.0005 \mathrm{kcal} / \mathrm{hr}$. deg. C. $l$ 以下と規定することに なった。

超低温断熱に必要な高い断熱効果を得るためには， 
断熱材を通しての入熱をできるだけ減らす必要があ る。断熱材を通しての侵入熱は, 次のような作用が同 時に起こることによって生じる。すなわち，

(1) 断熱材の空間にあるガスによる伝導 (対流)

（2）断熱材の固体部分とそれらの接触部を通しての 伝導

（3）空間部と断熱材を通しての輻射

これらの伝熱機構は同時に作用し，また互いに影響 し合うので個別に効果を上げようとしたり，全体の熱 伝導を求めたりすることは不可能である。そこで見掛 けの熱伝導を実験的に測定し, 次の基本式から入熱量 を推算しなければならない。

$$
q=k A\left(T_{1}-T_{2}\right) / L
$$

$q$; 断熱材を通しての入熱量, $k$; 見掛けの熱 伝導率, $A$; 平均表面積, $T_{1}, T_{2}$; 境界温度,

$L$; 断熱材の厚さ

断熱材の空間に存在するガス体は断熱材部材間の熱 接触をよくするので，ガスの除去によって図 4 に示す

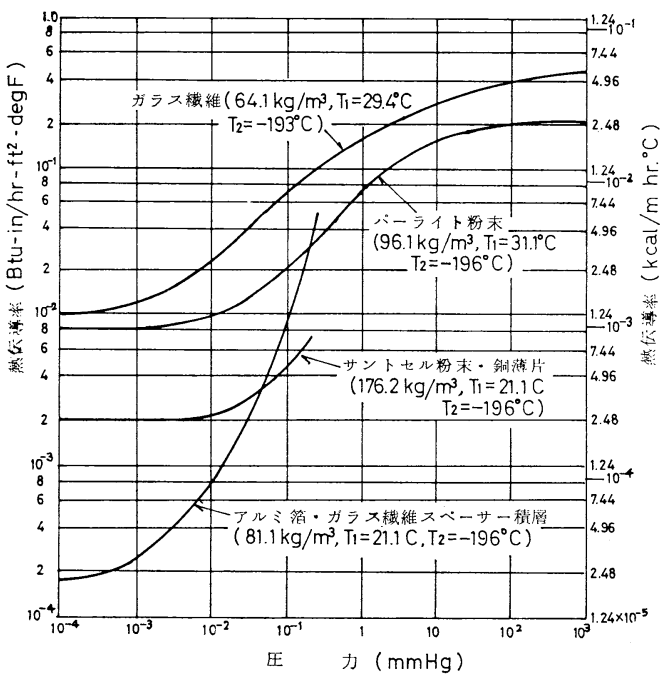

図 4 粉末, 緎維, 積層断熱材の熱伝導率に対す るガス圧カの影響

ように断熱効果を大幅に増加させることができる。所 要の断熱効果を得るために必要な真空度はガスの運動 理論から導かれる。それは，ガスの熱伀達率がガス分 子の平均自由行程とガス密度に比例していることを示 しており, その効果は真空度の範囲によって次のよう に分けられる。

(1) 大気圧から数 Torr の範囲ではガスによる伝導 は圧力に無関係である。

(2) 数 Torr（約 10Torr）以下ではガスによる伝導
は圧力に関係がある。

ガスによる伝導は断熱材の分子の直径, 輻射層の空 間, 気孔の径とその分布など断熱材固有の要素により 変化する。また断熱材部材間の空間が大きくなれば大 きくなるし，圧力の影響をうける範囲では圧力が低い ほど少なくなるが，この範囲では断熱材はまだ残留ガ スによる伝導, 断熱材部材間の固体熱伝導, 輻射によ って熱を伝導している。

輸送容器には一般にパーライトが使用され, 真空度 は 50 Micron Torr 程度にしている。わが国大手酸 素メ一カ一は, 自社あるいは系列会社において低温機 器を製作しているので, 自家用ローリーの真空低下に 対して再真空引きが可能であることと, 充てん容器の 真空度が空容器において到達した真空度の $1 / 10$ 以上 になることから, 容器単体の真空度は再真空引きを必 要とする期間内における洩れ量の限度を定め, パーラ イト充てん後の到達真空度を 100 Micron Torr 程度 にとどめるといった手法がとられている。

真空断熱方式の LNG ローリーでは, 断熱層の絶対 圧力を測定するために真空計取付口を設けることにな っているので, 真空度を測定することにより断熱性能 を判断することができる。しかし真空度の測定を行な らと断熱空間に一部大気が入り真空劣化の原因になる ので通常は真空度の測定による保守管理は行なわず, 自然昇圧速度により断熱性能や再真空引きの時期を把 握するよう日常の業務で心掛けなければならない。

再真空引きを必要とする期間は通常 LNG ローリー にはポンプあるいは加圧蒸発器が設けられるので, 省 令上, 移動式製造設備であり, 年 1 回以上の自主保安 検查を行ない, 年 1 回以上官庁の保安検査を受けるこ とが必要であるから，その機会をインターバルとして 定めることが望ましいであろう。また省令に定める容 器再検査の期間ごとに断熱性能試験が行なわれるが, このような定期的なチェック以外に所要の断熱性能が 維持されるよう常によく管理しなければならない。

\section{6. 容器付属品}

6-1 安全放出装置

LNG ローリーの容器には, 容器の耐圧試験圧の $80 \%$ 以下の圧力で作動する安全弁 (主安全弁) と $4 \mathrm{~kg} /$ $\mathrm{cm}^{2}$ 以下の圧力で作動する安全弁（副安全弁）を設け る。主安全弁はバネ式またはラプチャーディスクと し, その必要吹出量は加圧蒸発器の発生ガス量以上の 吹出能力を有するものとする。副安全弁は充てん限度 設定に関係しており, 液膨張で満杯する直前（空間率 $2.0 \%$ ）で作動させることを前提としているので，火 
災時などによる気化ガスに対応しうる吹出能力を有す るものとしている。

主副それぞれの安全弁は，目的を異にしているが， 取扱い上のミスにより両方とも殺された状態にならぬ よう，切換三方弁をそれぞれの安全弁の元弁として設 けることを規定している。加圧蒸発器使用時は主安全 弁のみ生きており, 液払出し作業中に火災が起こった 場合には速やかに移充てんを中止し（液およびガスラ インの緊急遮断弁を作動させる), かつ副安全弁へ切 り換える必要があるので切換三方弁は移充てんライン の緊急遮断弁同様に急速な切換えが遠隔操作できるこ とが望まれる。

ラプチャーディスクは, 従来補助的なものと考えら れ, 非常に安価な平板式のものが使用される傾向があ った。平板のものは破裂圧力を破裂試験で確認して も，同一の母材から採取したものに，ばらつきがある のみならず，長時間使用している間に生じた変形ある いはクリープ現象により, 当初設定した圧力で破裂し ないことが知られているので，委託基準ではドーム形 のものを使用するよう規定した（日本高圧力技術協会 基準 HPISG-101 ラプチャーディスク基準に準 拠す る)。

また, 容器には内槽の異常な圧力上昇に対処して, 手動でガス放出させるための放出弁が設けられる。

配管部において弁と弁の間で液封状態が生じるお抒そ れのある部分に対し配管安全弁が設けられる。以上の 安全放出装置は, いずれも安全な場所で上方に向かっ て放出するように配置される。

6-2 測定装置

容器への充㙗はトラックスケール上においてなされ るのが液化ガス充てんの通例であるが，充てん定数を LNG に対し第 1 種と第 2 種の LNG に区分し，ロー リーの容器をその区分に応じて標示するので，その標 示に合った LNG を内容積の $90 \%$ まで充てんすること は, 高圧ガス取締法も車両法上も適合するものとな る。したがって LNG ローリー容器には, 差圧式液面 計など内槽の液位を指示する液面計と，90\%以上の充 てんを防止するための過充てん防止固定チューブゲー ジが設けられる。

圧力計としては内槽圧力を示すものとして，運転台 から運行中にも監視できるものと, 移充てん作業にお いて弁操作室で監視できるものとが設けられる。弁操 作室の圧力計は安全弁作動圧力, 加圧蒸発器による加 圧時の作時圧力, 気密試験圧力など, その容器に必要 な圧力関係の数值を目盛板に標示することが必要であ
る。

また真空断熱容器には断熱空間の真空度を測定する ための真空計取付口が設けられる。

6-3 加圧蒸発装置

容器内の LNG を払い出す場合には, 加圧蒸発器に より内槽内を加圧して行なうのが普通である。LNG を内槽底部より加圧蒸発器に送り, ここで熱交換によ り蒸発させ，気化したガスを内槽気相部へ戻すことに よって内槽圧力を昇圧することができる。液払出し作 業中連続で昇圧操作を行ならと内槽内圧力は, 最高使 用圧力を越え主安全弁が作動するので，これを防止す るため圧力調整弁を加圧配管中に設ける場合が多い。

6-4 車両および車両付属品

車両とは道路運送車両法でいう自動車であって，タ ンクローリー, セミトレーラーが LNG 運送自動車と して考えられる。セミトレーラーは構造㧤よび制動性 能について車両保安基準上, 整備されていない面があ り, また危険物輸送の安全性からみて時期尚早とする 運輸省および消防庁の意見を勘案して，委託基準では トラックシャシーに容器を架装するタンクローリーに ついてのみ規定することになった。トラックの大型化 に伴い総重量 $20 \mathrm{t}$, エンジン馬力 $230 \mathrm{ps}$ 前後のロー リーが一般化している。車両付属品として消火器, 接 地用アースのほか, 自動車の電気系統, 排気管装置, リアバンパ，車側および後面に対するプロテクタ，車 両高さ検知棒などについて規定している（図 5 )。

タンクローリーの転覆事故はかなり聞くところであ り, 保安基準の改正で最大安定傾斜角度は $36^{\circ}$ 以上必 要である。これは輸送費低減のため，少しでも多く積 載したいとするユーザーの要求に対し, 総重量 $20 \mathrm{t}$ の 限度一杯に設計しなければならないメーカーにとって 軽量化設計（アルミ合金製容器）に努力がかかってい る。

\section{7. 取扱 い}

LNG ローリーの取扱いは高圧ガス取締法上では液 酸車や LNG ローリーと同様, 移動中に打ける災害防 止のため運行に先立ち通産局長へ移動計画書を提出し て, 移動中の安全性について確認を受けなければ使用 できない。運行中は絶えず移動監視者が保安の監視に 当たり $200 \mathrm{~km}$ 以上運行する場合は交代運転手を同乗 させ齐ばならぬ規定がある。運転者自から移動監視者 の資格をとる場合が多いが，資格は定められた講習と 実習ならびに筆記試験に合格した者に与えられる。

ポンプあるいは加圧蒸発器を有するローリーは法令 上容器証明書を受けるほか，移動式製造設備としての 

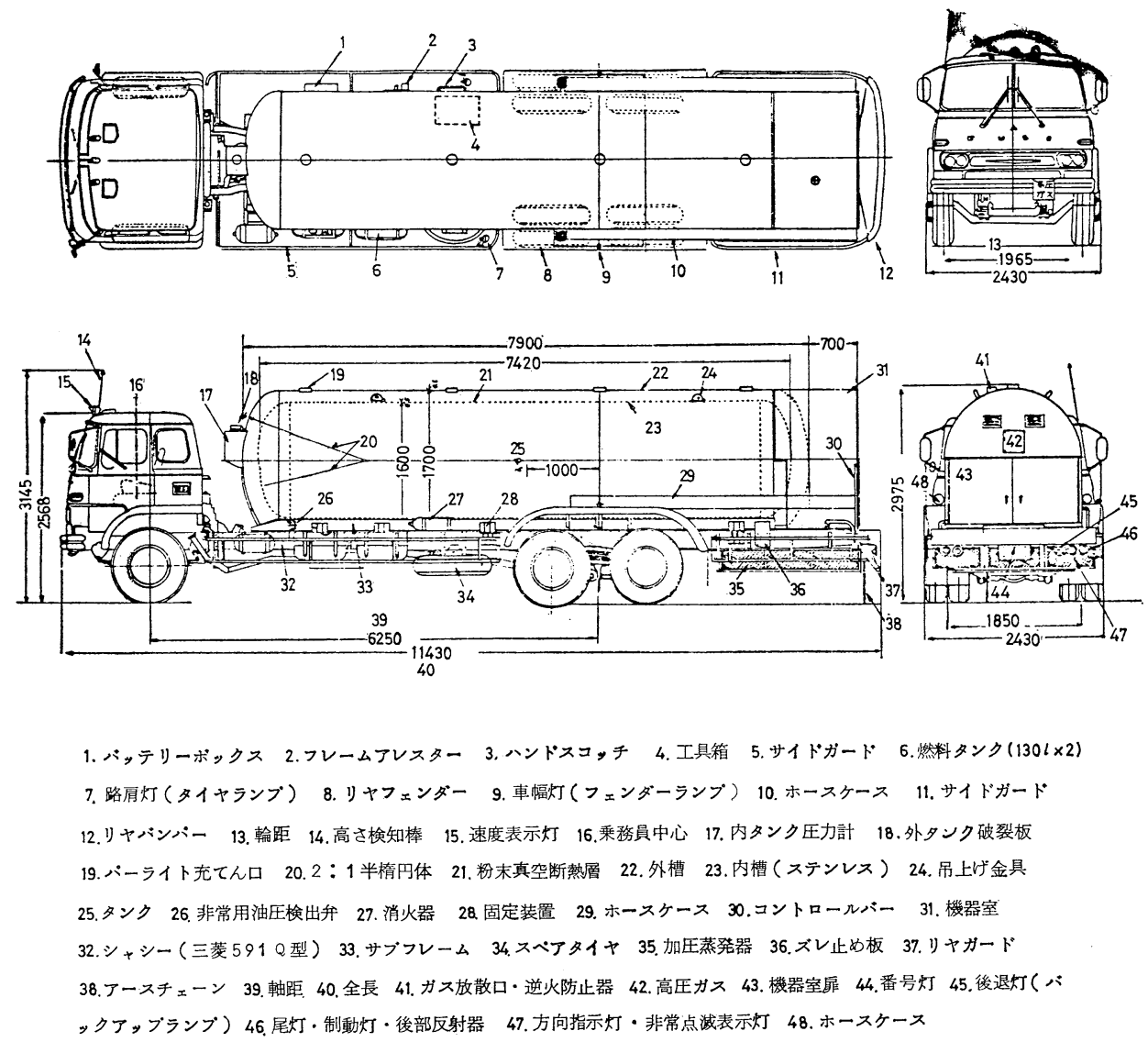

図 5 タンクローリー各部の名称（東京液化ガス提供）

規制を受けるので完成検查に合格し，かつ 1 年 1 回以 上の自主保安検查を行ない, 毎年 1 回官庁の行なら保 安検査を合格する必要がある。容器の部分については 超低温容器としての容器再検查に合格する必要があ る。移動監視者は運行中の保安監視に当たるのであっ て, ガスを取り扱ら事業所内での移充てん作業は, そ の事業所に属する高圧ガス作業主任者によって行なわ れるので, 移充てん作業を自らやってはならないこと になっている。また移動式製造設備の規制を受ける口 ーリーの所有者自から高圧ガス作業主任者を専任して 車庫および受入側での保安について管理しなければな らないことになっているので, LNG および液化エチ レンのローリー所有者は注意が必要である。

ローリーに対する日常の管理や点検, 作業心得など については委託基準に詳細に示されている。
LNG ローリーのポンプはわが国では開発されてお らず，欧米においてもほとんどが加圧蒸発器により払 出しが行なわれている。この加圧蒸圧器は高圧ガス製 造設備としての規制の適用を受けるとの法令上の運用 解採に基づき前述のとおり移動式製造設備として取り 扱うものとし説明したが, 過去の液酸車の加圧蒸発器 の取扱いに関する法令運用上の経緯をみると, 自動圧 力制御装置をもつ加圧蒸圧器であって, 加圧する圧力 が $10 \mathrm{~kg} / \mathrm{cm}^{2}$ 以上のものを製造設備とし, $10 \mathrm{~kg} / \mathrm{cm}^{2}$ 未満のものは製造設備として取り扱われなかったもの であるが，41化第 685 号通達で製造許可の対象となっ た。高圧ガス取締月報 No. 85 (47-2) に製造, 貯蔵, 消費の境界域の類型について事例をもって, 具体的に 運用解勫が明らかにされ, かつ処理能力の確認方法が 定められているので参考にされたい。 
8. おわりに

本稿については高圧ガス保安協会の御許可を得て,
委託基準作成委員会での資料を利用させていただいた ことを厚くお礼申し上げます。

\title{
The Outline of Tank Lorry from a View-Point of Designing
}

\author{
by S.Adachi \& Y.Shimizu
}

(Kawasaki Heavy Industries, Ltd.)

SYNOPSIS : - Demand for energy is increased more and more in Japan and to supply it we owe a great deal to petroleum. But the spread of environmental pollution becoming the topic in these days, much is expected of LNG as pollution-free energy.

LNG base are about to be in operation in Negishi area in Yokohama and in Senpoku area in Osaka. In the near future metanization will be in immense progress, which will being about many a satellite station here and there.

As a transportation system for LNG among these satellite strage bases, tank cars and/or tank lorries will be taken into consideration without fail.

Accordingly, the outline of tank lorry is described hereunder by explaining some problems from a view-point of designing, including its handling and maintenance. 